\title{
NWINEEWII, J. D \\ HEAVY METALS CONTAMINATIONS IN SURFACE SOILS WITHIN BORI, RIVERS STATE, NIGERIA.
}

\author{
jnwineewii@yahoo.com \\ Department of Chemistry, Faculty of Natural and Applied Sciences, Ignatius Ajuru University of Education Rumuolumeni, \\ Port Harcourt., Nigeria.
}

This article is covered and protected by copyright law and all rights reserved exclusively by the Centre for Petroleum, Pollution Control and Corrosion Studies (CEFPACS) Consulting Limited.

Please note that the opinion expressed in this article remain that of the author(s). Electronic copies available to authorised users.

The link to this publication is https://ajoeer.org.ng/otn/ajoeer/qtr-1/2021/08.pdf 


\title{
Heavy Metals Contaminations in Surface Soils within Bori, Rivers State, Nigeria.
}

NWINEEWII, J. D

Department of Chemistry, Faculty of Natural and Applied Sciences, Ignatius Ajuru University of Education Rumuolumeni, Port Harcourt.

\author{
jnwineewii@yahoo.com
}

Received: December 08, 2020; Received in reversed form: December 24, 2020; Accepted: December 28, 2020.

\begin{abstract}
Heavy metal contaminations in surface soils within Bori were examined. The composite soil sample at $10-15 \mathrm{~cm}$ depth was collected from each of the seven sampling locations including the control location using a stainless-steel hand auger. The soil samples were air-dried for 2 days, homogenized and sieved through a $2 \mathrm{~mm}$ mesh to obtain uniform size. The soil samples were subjected to wet digestion method using nitric-perchloric acid. The digested samples were used for determination of concentrations of the heavy metals $(\mathrm{Cd}, \mathrm{Cr}, \mathrm{Ni}, \mathrm{Mn}, \mathrm{Pb}, \mathrm{Fe} \mathrm{Cu}$ and $\mathrm{Zn}$ ) using the atomic absorption spectrophotometer (AAS). The mean concentrations of the heavy metals obtained ranged as follows: $\mathrm{Pb}(0.553-4.551 \mathrm{mg} / \mathrm{kg}), \mathrm{Cr}(1.713-7.965 \mathrm{mg} / \mathrm{kg}), \mathrm{Cd}(0.011-2.549 \mathrm{mg} / \mathrm{kg}), \mathrm{Mn}(6.914-40.162$ $\mathrm{mg} / \mathrm{kg}), \mathrm{Ni}(2.942-6.597 \mathrm{mg} / \mathrm{kg}), \mathrm{Zn}(4.468-13.976 \mathrm{mg} / \mathrm{kg})$ and $\mathrm{Cu}(1.90-11.503 \mathrm{mg} / \mathrm{kg})$. The results were below the world average values except Fe $(53.554-122.203 \mathrm{mg} / \mathrm{kg})$. The enrichment factor values ranged between 0.04 and 20.86 and showed low to moderate enrichment due to anthropogenic activities. The pollution load index (PLI) value was 1 , the combined pollution index (CPI) values ranged between 0.39 and 1.73 and the metal pollution load index (MPL) value of $3.73>$ 1 revealed pollution in urban surface soils of the study area. The high positive correlation result among the heavy metals in the sample soils of the study area suggested that they are of similar pollution sources. Based on the findings, the urban surface soils of the study area are contaminated with heavy metals. Therefore, there should be monitoring and environmental audit by relevant authorities to ensure adequate environmental quality of urban surface soils in the study area.
\end{abstract}

Keywords: Heavy metals, contaminations, Bori, metal pollution load, combined pollution index.

\section{0: INTRODUCTION}

Migration of people from rural to urban cities has increased human population density resulting into generation of large agricultural and municipal wastes containing heavy metals as contaminants (Onwudikeet al., 2017). These wastes are deposited on or along the roadsides, unapproved areas, open dumpsites in the markets or in water ways which lead to pollution and contamination of heavy metals.

Heavy metal contents of urban soils are of major significance due to their non-degradable nature and ability to accumulate for long period of time. The studies carried out by Marcus et al., (2017), Nwineewii and Nna, (2016) revealed that heavy metals exhibited certain metallic properties which distinguished them from other metals. These heavy metals are known to be toxic when they reach or exceed certain concentrations in food, water, soil and air, although some of them are very important to humans, animals and plants at trace levels. The presence of heavy metals in an environment alters 
the structure and functions of the ecosystem. This is attributed to the fact that their presence has effect or influence on the nature of the physical and chemical properties of urban soil.

Bori urban is one of the urban areas with various anthropogenic activities including electrical, clothing, jewelry, furniture shops, supermarkets, fuel stations, numerous automobile services and repair workshops. Increased artesian and automobile repair workshops which include auto mechanic, auto welding, auto electrician and auto painting units may create varieties of wastes which contain heavy metals in course of their daily operations. These wastes include used oil, and fluids, dirty shops rags, used parts, asbestos from brake pads and wastes from solvents used for cleaning parts which contain heavy metals that are dangerous to human and the environment (Liang et al., 2011).

Innumerable studies have been carried out in many cities around the world, investigating the heavy metal contents in urban soils. For instance, Salah, et al., (2015) worked on heavy metals in urban soils in Baghdad city, Iraq, Mohammed et al., (2015) worked on heavy metals in soils of Sirte city, Libya; Wang et al., (2017) did work on heavy metals in urban soils within Suzhou city, China, all the findings of these investigations revealed elevated concentrations of heavy metals in urban soils. Al Obaidy\&Mashhadi2013) worked on heavy metals in urban soil within Baghdad city, Iraq, reported in their study the contamination of urban soil with heavy metals.

In Nigeria, studies have equally been carried out on heavy metals in urban soils. Onwudikeet al., (2017) worked on heavy metals of Owerri soil; Ekwereet al. (2014) carried out a study on the distribution of heavy metals in urban soils; a case study of Calabar Area, South-Eastern Nigeria; Iwegbueet al., (2013) did a work on the assessment of heavy metal contamination in soils around cassava processing mills in sub-urban areas of Delta State, Southern Nigeria; Edori and Kpee (2017) carried out a study on index models assessment of heavy metal pollution in soils within selected abattoirs in Port Harcourt, Rivers State, Nigeria. The findings of these researches revealed that the soil samples under study were highly contaminated or polluted with heavy metals. None of these studies investigated heavy metals in Bori urban surface soil, thereby creating a gap that needs to be filled. Studies concerning heavy metal contamination in urban soils are needed to develop strategies to protect urban environments and human health against long-term accumulation of heavy metals. The present study seeks to investigate heavy metals contaminations in surface soils within Bori. 


\section{0: MATERIALS AND METHODS}

\section{1: Soil Sample Collection and Analysis}

Soil samples were collected from seven (7) selected study locations at $10-15 \mathrm{~cm}$ depth including the control location and collected with the aid of a stainless-steel hand auger. Three soil samples from each sampling location were randomly collected to make a composite sample. The collected composite samples were stored in properly labeled polythene bags until time for analysis.

Soil samples were air-dried for 2 days, homogenized and sieved through a $2 \mathrm{~mm}$ mesh to obtain uniform size. The soil samples were subjected to wet digestion method using nitric-perchloric acid in line with the works of (Ogunkunle et al., 2013; Oladeji et al., 2016).2 grams of each sample were weighed into a $50 \mathrm{ml}$ beaker, then added to the sample were $20 \mathrm{mls}$ and $10 \mathrm{mls}$ of concentrated nitric acid $\left(\mathrm{HNO}_{3}\right)$ and perchloric acid $\left(\mathrm{HClO}_{4}\right)$ respectively for 30-45 minutes under gentle heating at 60 ${ }^{\circ} \mathrm{C}$. The solution was allowed to cool and was filtered into a $50 \mathrm{ml}$ volumetric flask and made up to the $50 \mathrm{ml}$ mark with distilled water. The digested samples were used for determination of concentration of the heavy metals of interest $(\mathrm{Cd}, \mathrm{Cr}, \mathrm{Cu}, \mathrm{Ni}, \mathrm{Mn}, \mathrm{Pb}, \mathrm{Fe}$ and $\mathrm{ZN})$ using the Atomic Absorption Spectrophotometer (AAS).

\section{2: Contamination Indices for Heavy Metal Analysis}

To determine the status of contamination in the study area the following pollution indices were used:

\subsection{1: Enrichment Factor (EF)}

Enrichment factor was used to differentiate between heavy metals from anthropogenic source and natural source. It was also used to investigate the degree of contamination and that of anthropogenic impact (Salah et al., 2013). The enrichment factor was calculated using the equation proposed by Ali et al., (2015) as follows:

$\mathrm{EF}=\frac{\frac{C n}{\text { Cref }} \text { of sample }}{\frac{C n}{\text { Cref }} \text { of reference metal }}$

Where: $\quad \mathrm{Cn}$ is the concentration of metal in soil sample $(\mathrm{mg} / \mathrm{kg})$

Cref is the concentration of reference metal in soil sample $(\mathrm{mg} / \mathrm{kg})$.

In this study, Fe was adopted as reference metal because it is difficult to modify Fe by anthropogenic activities. The EF was classified into 5 contamination categories as indicated in Table1 below 
Table 1: Classification of Enrichment Factor

\begin{tabular}{ll}
\hline Enrichment Factor (EF) & Classification \\
\hline $\mathrm{EF}<2$ & Minimal enrichment \\
$\mathrm{EF}=2-5$ & Moderate enrichment \\
$\mathrm{EF}=5-20$ & Significant enrichment \\
$\mathrm{EF}=20-40$ & Very high enrichment \\
$\mathrm{EF}>40$ & Extremely high enrichment \\
\hline
\end{tabular}

Source:Aliet al., (2013).

\subsection{2: Pollution Load Index (PLI)}

The extent of metal pollution for each sampling site was evaluated based on Pollution Load Index (PLI) adopted by Mmolawaet al., (2011) as follows:

$$
P L I=\sqrt[n]{C F, \times C F_{2}} \times C F_{3} \times C F_{n} \ldots \ldots \ldots \ldots \ldots \ldots \ldots
$$

Where: $\mathrm{n}$ is the number of metals studies

Where CF is the contamination factor as calculated using equation by Hamid et al., (2016)

Cf $\frac{\text { Sample }}{\text { Ref }}$

The PLI provides simple but comparative means for assessing a sampling site quality. When the value of PLI $<1$, it denotes non-pollution and when PLI > 1, it indicates pollution.

\subsection{3: Pollution Index (CPI)}

It was stated by Karim et al., (2015) that some heavy metal contamination in the surface soil was associated with a mixture of contaminants rather than one metal contamination. They projected that the concept of a Combined Pollution Index (CPI) can be used as another commonly evaluation methods of heavy metal accumulation and to identify multi-element contamination which results in increased over all metal toxicity. Nezhad et al., (2015) proposed that CPI is calculated using this equation.

$$
C P I=\frac{\text { Metal content in soil } / \text { permissible level of metal }}{\text { Number o fmetals }}
$$

They classified the calculated values of CPI indicated in Table 3.3.

\section{Table 2: Classification of CPI Values}

\begin{tabular}{ll}
\hline CPI Values & Classification \\
\hline CPI $\leq 1$ & Low multi-element contamination \\
\hline
\end{tabular}


$1<\mathrm{CPI}<2$

$\mathrm{CPI}>2$
Middle multi-element contamination

High multi element contamination

Source: Nezhad et al., (2015).

Wang et al., (2012) further classified CPI values that if CPI $\leq 1$ indicates no heavy metal accumulation in soil and if CPI > 1 indicates heavy metal accumulation in soil.

\subsection{4: Metal Pollution Index (MPI)}

According to Sarala \& Uma (2013), Metal Pollution Index (MPI) was calculated to enable the results from the metal concentrations for the study to be presented as one value. This implies that the heavy metal concentrations for the study must be normalized to make it possible to sum up and average the different metal concentrations into one value. Thus, MPI is calculated using the equation.

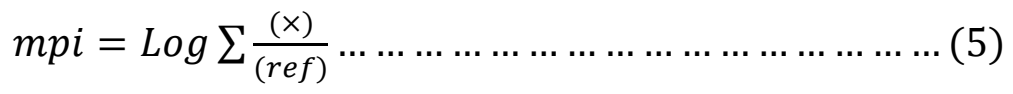

Where:MPI = Metal pollution index

$$
\begin{aligned}
& (\mathrm{x}) \quad=\quad \text { Mean value of metal concentration from the sampling sites. } \\
& \text { Ref } \quad=\quad \text { Reference value for each of heavy metals for the study. }
\end{aligned}
$$

If MPI $<1$ it indicates non pollution and

If MPI > 1 it indicates pollution.

\subsection{5: Statistical Analysis}

Statistical analysis was used based on descriptive statistics where minimum and maximum values, mean and standard deviation values were calculated. Pearson correlation matrix was equally used to identify the level of interactions between the heavy metals under study.

\section{0: RESULTS AND DISCUSSION}

The statistical analyses of the concentrations of heavy metals are presented in Table 4.

\section{1: Heavy Metals Distribution}

Distributions of heavy metals in the various sampling locations of the study area in the summary of mean concentrations with standard deviations are presented in Table 4. The various land use areas have the mean concentrations of the heavy metals. 


\subsection{1: Lead (pb)}

From the results in Table 4 below, the mean concentrations of Lead $(\mathrm{Pb})$ in the land use areas range from $0.553 \mathrm{mg} / \mathrm{kg}$ to $4.581 \mathrm{mg} / \mathrm{kg}$. The motor part area was with the highest mean value of 4.581 $\mathrm{mg} / \mathrm{kg}$ and the hospital area was with the lowest mean concentration $0.553 \mathrm{mg} / \mathrm{kg}$. The sequence of lead distribution in the land use area were motor park (4.581) > market area (3.489) > major road side (3.120) > residential area $(1.718)>$ school area $(0.750)>$ hospital area $(0.553)$.The mean concentrations of $\mathrm{Pb}$ in the sampling locations were higher than the mean concentration of the control sample $(0.220 \mathrm{mg} / \mathrm{kg})$. The mean concentrations of $\mathrm{Pb}$ in all the sampling locations were below the world average of unpolluted soils (44 mg/kg) (Alobaidyet al., 2013). 
Table 4: The mean concentrations $(\mathrm{mg} / \mathrm{kg})$ of heavy metals in soil samples from various locations.

\begin{tabular}{|c|c|c|c|c|c|c|c|c|}
\hline \multirow[t]{2}{*}{ Sampling Locations } & \multicolumn{7}{|c|}{ Heavy Metals } & \multirow[b]{2}{*}{$\mathrm{Fe}$} \\
\hline & $\mathrm{Pb}$ & $\mathrm{Cr}$ & $\mathrm{Cd}$ & $\mathrm{Mn}$ & $\mathrm{Ni}$ & $\mathrm{Zn}$ & $\mathrm{Cu}$ & \\
\hline Motor Park & $4.581 \pm 0.38$ & $7.965 \pm 0.17$ & $2.549 \pm 0.14$ & $40.162 \pm 0.65$ & $6.597 \pm 0.48$ & $13.976 \pm 0.40$ & $11.503 \pm 0.54$ & $122.203 \pm 0.88$ \\
\hline Motor Road side & $3.120 \pm 0.41$ & $5.271 \pm 0.56$ & $1.503 \pm 0.40$ & $30.398 \pm 0.49$ & $4.965 \pm 0.14$ & $9.769 \pm 0.09$ & $7.70 \pm 0.28$ & $105.367 \pm 1.43$ \\
\hline Market Area & $3.489+0.49$ & $6.883+0.40$ & $1.739+0.18$ & $24.474 \pm 0.51$ & $5.768+0.17$ & $11.206 \pm 0.08$ & $8.537 \pm 0.43$ & $92.931 \pm 0.36$ \\
\hline Residential Area & $1.718 \pm 0.26$ & $3.736 \pm 0.18$ & $0.431 \pm 0.38$ & $10.743 \pm 0.18$ & $3.649+0.38$ & $7.770 \pm 0.24$ & $4.870 \pm 0.12$ & $67.664 \pm 0.44$ \\
\hline School Area & $0.750 \pm 0.15$ & $2.891 \pm 0.31$ & $0.011 \pm 0.00$ & $5.718 \pm 0.27$ & $1.912 \pm 0.27$ & $4.392 \pm 0.49$ & $2.742 \pm 0.16$ & $60.369 \pm 1.18$ \\
\hline Hospital Area & $0.553 \pm 0.11$ & $1.713+0.24$ & $0.011 \pm 0.00$ & $6.914 \pm 0.19$ & $2.942+0.12$ & $4.468 \pm 0.51$ & $1.910+0.13$ & $53.554 \pm 1.07$ \\
\hline Control Sample & $0.220 \pm 0.00$ & $0.204+0.04$ & $0.001 \pm 0.00$ & $2.966 \pm 0.02$ & $0.165+0.16$ & $2.477 \pm 0.07$ & $0.156 \pm 0.00$ & $46.525 \pm 0.51$ \\
\hline $\begin{array}{l}\text { World Average of unpolluted soils (AI Obaidy } \\
\text { and Mashhadi, 2013) }\end{array}$ & 44 & 83 & 0.53 & 525 & 34 & 100 & 24 & 53 \\
\hline WHO standard value (Onwudikeel al., 2017) & 0.10 & 5.00 & 0.01 & 20 & 5.00 & 10 & 10 & 10 \\
\hline World Average Shale (Fazeliet al., 2018) & 20 & 39 & 0.30 & 850 & 68 & 95 & 39 & $4.7(\%)$ \\
\hline Mean earth crust value (Barbieri 2016) & 14 & 100 & 0.1 & 950 & 80 & 75 & 50 & $4.4(\%)$ \\
\hline
\end{tabular}


However, the mean concentrations of $\mathrm{Pb}$ in all the sampling stations were above the WHO standard values $(0.10 \mathrm{mg} / \mathrm{kg})$ (Onwudike et al., 2017).

The results of this study agree with the findings from the studies of Alobaidy et al., (2013), Proshad et al., (2019) and Onwudike et al., (2017), on heavy metal contaminations in urban soil in Baghdad City, Iraq and Owerri, Nigeria respectively. The findings of this study revealed the same sequence of $\mathrm{Pb}$ distribution in different land use areas, showing that the mean concentration of $\mathrm{Pb}$ was below the world average unpolluted soils and above the WHO standard values. Pb can enter the urban soils during various anthropogenic activities and it can be very toxic to health. Deposition related to transportation activities can contribute to accumulation of $\mathrm{Pb}$ in motor parks, roadside and market surface soils. Hence $\mathrm{Pb}$ has been shown to accumulate to high levels in urban surface soil from range of sources including that derived from leaded gasoline (Jin et al., 2014). Ogundele et al., (2015) reported that the high concentration of $\mathrm{Pb}$ depicts the urban soil was polluted due to human activities such as fuel combustion and vehicular emissions. They supported the fact that lead has toxic properties and was found in large amounts in many electronic devices, because, it is a major constituent of lead-acid battery extensively used in car batteries and tyres which could end up in soil through corrosion.

\subsection{2: Chromium (Cr)}

The chromium mean concentration varies from $1.713 \mathrm{mg} / \mathrm{kg}$ to $7.915 \mathrm{mg} / \mathrm{kg}$ as indicated in Table 4. This result shows that the sequence of the mean concentration was in the order of motor park $(7.915 \mathrm{mg} / \mathrm{kg})>$ market area $(6.883 \mathrm{mg} / \mathrm{kg})>$ major road side $(5.271 \mathrm{mg} / \mathrm{kg})>$ residential area $(3.736 \mathrm{mg} / \mathrm{kg})>$ school area $(2.891 \mathrm{mg} / \mathrm{kg})>$ hospital area $(1.713 \mathrm{mg} / \mathrm{kg})$. This indicates that the motor park has the highest mean concentration while hospital area has the lowest. Of course, the mean concentrations of $\mathrm{Cr}$ in the different sampling locations were above the mean concentration of the control sample $(0.204 \mathrm{mg} / \mathrm{kg})$. The observed values of $\mathrm{Cr}$ are below the world average value of unpolluted soils $(83.0 \mathrm{mg} / \mathrm{kg}$ ) (Alobaidy et al., 2013). The observed mean values of motor park $(7.965 \mathrm{mg} / \mathrm{kg})$, major road side $(5.271 \mathrm{mg} / \mathrm{kg})$ and that of market area $(6.833 \mathrm{mg} / \mathrm{kg})$ were above WHO standard value $(5.00 \mathrm{mg} / \mathrm{kg})$ while those of residential area $(3.736 \mathrm{mg} / \mathrm{kg})$, school area $(2.891 \mathrm{mg} / \mathrm{kg})$ and hospital area $(1.713 \mathrm{mg} / \mathrm{kg})$ were below the WHO standard value $(5.00 \mathrm{mg} / \mathrm{kg})$. 


\subsection{3: Cadmium (Cd)}

The Cadmium (Cd) mean concentration varies from $0.011 \mathrm{mg} / \mathrm{kg}$ to $2.549 \mathrm{mg} / \mathrm{kg}$, with motor park having the highest value $(2.549 \mathrm{mg} / \mathrm{kg})$ and the hospital area having the lowest value of 0.011 $\mathrm{mg} / \mathrm{kg}$. The sequence of the mean concentrations of the land use areas are in the order of motor park $(2.549 \mathrm{mg} / \mathrm{kg})>$ market area $(1.739 \mathrm{mg} / \mathrm{kg})>$ major road side $(1.503 \mathrm{mg} / \mathrm{kg})>$ residential area $(0.431 \mathrm{mg} / \mathrm{kg})>$ school area $(0.011 \mathrm{mg} / \mathrm{kg})$ and hospital area $(0.011 \mathrm{mg} / \mathrm{kg})$ as shown in Table 4 above. The observed values of the heavy metals in various sampling locations of the study area were above the mean concentration $(0.001 \mathrm{mg} / \mathrm{kg})$ of the control sample.

The observed values of Motor Park $(2.549 \mathrm{mg} / \mathrm{kg})$, major roadside $(1.503 \mathrm{mg} / \mathrm{kg})$ and market area $(1.739 \mathrm{mg} / \mathrm{kg})$ were above the world average of unpolluted soils $(0.53 \mathrm{mg} / \mathrm{kg})$ but those of residential area $(0.431 \mathrm{mg} / \mathrm{kg})$, school area and hospital area of $0.011 \mathrm{mg} / \mathrm{kg}$ each were below the world average of unpolluted soils. However, the observed values of the various sampling locations were above the WHO standard value $0.01 \mathrm{mg} / \mathrm{kg}$ as indicated in Table 4.

The findings of the study done by Lu \&Bai (2010) agree with the results of this study. In their studies on assessment of metal contamination in soils samples of Nashik, District, India, the finding revealed that $\mathrm{Cd}$ amongst other metals like $\mathrm{Cu}, \mathrm{Zn}, \mathrm{Cr}$ and $\mathrm{Ni}$ was found in more concentration of all the stations under investigation. The mean concentrations above $0.53 \mathrm{mg} / \mathrm{kg}$ and $0.01 \mathrm{mg} / \mathrm{kg}$ could reflect the influence of human activities. The anthropogenic activities led to increase in the level of $\mathrm{Cd}$ as a result of urban-industrial and agricultural activities to the environment. Many anthropogenic activities can increase the level of $\mathrm{Cd}$ in urban soil surface well above background levels, such as the application of solid wastes from industries, homes. Cd could accumulate in the human body over a long period of time, and it is highly mobile and toxic (Lu and Bai, 2010).

\subsection{4: Manganese (Mn)}

The observed mean concentration of Mn varies from $6.914 \mathrm{mg} / \mathrm{kg}$ to $40.162 \mathrm{mg} / \mathrm{kg}$ indicating that motor park has the highest value $(40.162 \mathrm{mg} / \mathrm{kg})$ and the school area with the lowest value $(5.718$ $\mathrm{mg} / \mathrm{kg}$ ). The sequence of the observed mean concentrations are in the order to motor park (40.162 $\mathrm{mg} / \mathrm{kg})>$ major roadside $(30.398 \mathrm{mg} / \mathrm{kg})>$ market area $(24.474 \mathrm{mg} / \mathrm{kg})>$ residential area $(10.743$ $\mathrm{mg} / \mathrm{kg})>$ hospital area $(6.94 \mathrm{mg} / \mathrm{kg})>$ school area $(5.718 \mathrm{mg} / \mathrm{kg})$ as indicated in Table 4. The observed mean concentrations of $\mathrm{Mn}$ in the various sampling stations were below the world 
average of unpolluted of soil $525 \mathrm{mg} / \mathrm{kg}$. However, on comparison with the control sample value, all the observed mean concentrations were above the control sample mean concentration (2.966 $\mathrm{mg} / \mathrm{kg}$ ). This observation was in agreement with the finding of the study by Alobaidy et al., (2013) on heavy metal contaminations in urban soil within Baghdad. The findings of their studies revealed that the Mn observed values were less than the reported world average of unpolluted soil (525 $\mathrm{mg} / \mathrm{kg}$ ) and that these values of $\mathrm{Mn}$ in the studied soil samples were observed to be higher than the value of the rural soil samples being the control.

\subsection{5: Nickel (Ni)}

Nickel (Ni) mean concentration varies from $1.912 \mathrm{mg} / \mathrm{kg}$ to $6.597 \mathrm{mg} / \mathrm{kg}$ revealing that motor park has the highest value $(6.597 \mathrm{mg} / \mathrm{kg})$ and the school area with the lowest value $(1.912 \mathrm{mg} / \mathrm{kg})$. The sequence of the mean concentrations of $\mathrm{Ni}$ as indicated in Table 4.9 are in the order motor park $(6.597 \mathrm{mg} / \mathrm{kg})>$ market area $(5.768 \mathrm{mg} / \mathrm{kg})>$ major roadside $(4.965 \mathrm{mg} / \mathrm{kg})>$ residential area $(3.649 \mathrm{mg} / \mathrm{kg})>$ hospital area $(2.942 \mathrm{mg} / \mathrm{kg})>$ school area $(1.912 \mathrm{mg} / \mathrm{kg})$. The observed values are below the world average of unpolluted soil (34 mg/kg).Further, considering the analyzed value of the control sample as $0.165 \mathrm{mg} / \mathrm{kg}$, revealed that $\mathrm{Ni}$ mean concentrations of the various sampling stations were above the $\mathrm{Ni}$ value in the control sample.

Critically, looking at the mean concentrations of $\mathrm{Ni}$ from the various studied samples also revealed that the observed values were above the WHO standard value $(2.6 \mathrm{mg} / \mathrm{kg})$ except the mean value of $\mathrm{Ni}$ in the school area $(1.912 \mathrm{mg} / \mathrm{kg})$ that was below the WHO standard value. The result of this study is in agreement with the finding of the study by (Oladeji et al., 2016). The finding of their study revealed that the mean value of $\mathrm{Ni}(70.38 \mathrm{mg} / \mathrm{kg})$ obtained was higher than the recommended safe limit of $66.9 \mathrm{mg} / \mathrm{kg}$. They went further to acknowledge the primary source of nickel pollution to be from diesel fuel, gasoline and lubricating oil coming in contact with the soil. This makes the urban soil to have significant amount of $\mathrm{Ni}$ as a result of different human activities. Alobaidy et al., (2013) supported this position by reporting that Ni content of many domestic cleaning products, e.g. soap, $100-700 \mathrm{mg} / \mathrm{kg}$; powdered detergents $400-700 \mathrm{mg} / \mathrm{kg}$ and powdered bleach, $800 \mathrm{mg} / \mathrm{kg}$, may have significantly contributed to the sources of $\mathrm{Ni}$ in the urban surface soils. 


\subsection{6: Zinc (Zn)}

The mean concentration of $\mathrm{Zn}$ varies from $4.392 \mathrm{mg} / \mathrm{kg}$ to $13.976 \mathrm{mg} / \mathrm{kg}$, revealing the motor park has the highest value $(13.976 \mathrm{mg} / \mathrm{kg})$ and the school area $(4.392 \mathrm{mg} / \mathrm{kg})$ the lowest value. Following the sequence of the mean concentrations of $\mathrm{Zn}$ from the various sampling stations, the order are motor park $(13.976 \mathrm{mg} / \mathrm{kg})>$ market area $(11.206 \mathrm{mg} / \mathrm{kg})>$ major roadside $(9.769$ $\mathrm{mg} / \mathrm{kg})>$ residential area $(7.770 \mathrm{mg} / \mathrm{kg})>$ hospital area $(4.468 \mathrm{mg} / \mathrm{kg})>$ school area $(4.392 \mathrm{mg} / \mathrm{kg})$ as indicated in Table 4. In Table 4, the mean concentrations of $\mathrm{Zn}$ from various sampling locations were above the control sample $(2.477 \mathrm{mg} / \mathrm{kg})$ but all the observed values were below the world average of unpolluted soil $(100.00 \mathrm{mg} / \mathrm{kg})$. Comparing the observed values with the WHO value of $15.00 \mathrm{mg} / \mathrm{kg}$, all the observed values of $\mathrm{Zn}$ were below the WHO standard value $(15.00 \mathrm{mg} / \mathrm{kg})$. Michael et al., (2015), in their study carried out on the distribution and variation of heavy metals and soil properties in Gboko, equally found out the higher level of $\mathrm{Zn}$ as compared to the standard. In their study, the mean concentration of zinc was found to be $(76.69 \mathrm{mg} / \mathrm{kg})$, while the highest value was $123.45 \mathrm{mg} / \mathrm{kg}$ ) in the soil samples investigated. They deduced that $\mathrm{Zn}$ particles could be derived from Mechanical abrasion vehicles, as they are used in the production of brass alloy and from brake linings, oil leak pumps and cylinder head gaskets, which result into accumulation of high level of $\mathrm{Zn}$ in urban soils.

\subsection{7: Copper $(\mathrm{Cu})$}

The observed values of $\mathrm{Cu}$ varied from $1.910 \mathrm{mg} / \mathrm{kg}$ to $11.503 \mathrm{mg} / \mathrm{kg}$, showing that motor park with the highest value of $11.503 \mathrm{mg} / \mathrm{kg}$ and hospital area the lowest value of $1.910 \mathrm{mg} / \mathrm{kg}$. The sequential order of the mean concentration of $\mathrm{Cu}$ are in the order, motor park $(11.503 \mathrm{mg} / \mathrm{kg})>$ market area $(8.537 \mathrm{mg} / \mathrm{kg})>$ major roadside $(7.720 \mathrm{mg} / \mathrm{kg})>\operatorname{residential}$ area $(4.870 \mathrm{mg} / \mathrm{kg})>$ school area $(2.742 \mathrm{mg} / \mathrm{kg})>$ hospital area $(1.910 \mathrm{mg} / \mathrm{kg})$, as in Table 4 . The observed values of $\mathrm{Cu}$ are above the control sample $(0.156 \mathrm{mg} / \mathrm{kg})$ but all the observed values were below the world average of unpolluted soil $(24.00 \mathrm{mg} / \mathrm{kg})$. These results tend to support the finding of Li \& Tan (2016) who carried out study on distribution and risk evaluation of heavy metals in the soil of typical grassed swale. They found out that the concentration of $\mathrm{Cu}$ was between 138.6 - 167.3 $\mathrm{mg} / \mathrm{kg}$, which greatly exceeded the evaluation criteria and showed a heavy pollution condition. $\mathrm{Cu}$ contributions could be envisaged from dumping or accumulation of solid wastes, application of fungicides, livestock manures, sludges and atmospheric deposition (Alobaidy et al., 2013). Cu is used in numerous applications due to its physical properties. The toxicity of $\mathrm{Cu}$ for humans is not 
very high but its accumulation in urban soil can be explained by the bioaccumulation of the metal and anthropogenic activities (Meng et al., 2017).

\subsection{8: Iron (Fe)}

From table 4, the observed values of Fe ranged from $46.525 \mathrm{mg} / \mathrm{kg}$ to $122.203 \mathrm{mg} / \mathrm{kg}$, the observed values of $\mathrm{Fe}$ are in the order, motor park $(122.203 \mathrm{mg} / \mathrm{kg})>$ major road side $(105.367 \mathrm{mg} / \mathrm{kg})$ market area $(92.931 \mathrm{mg} / \mathrm{kg})>$ residential area $(67.664 \mathrm{mg} / \mathrm{kg})>\operatorname{school}$ area $(60.369 \mathrm{mg} / \mathrm{kg})>$ hospital area $953.554 \mathrm{mg} / \mathrm{kg})>$ control sample $(46.525 \mathrm{mg} / \mathrm{kg})$. All the observed values of heavy metals in this study were greater than the $53 \mathrm{mg} / \mathrm{kg}$ of the world average of unpolluted soils (Alobaidy \& Mashhadi, 2013), $10 \mathrm{mg} / \mathrm{kg}$ of WHO standard value (Onwudike et al., 2017), 4.7\% of world average shale value (Fazeli et al., 2018) and $46.525 \mathrm{mg} / \mathrm{kg}$ of the control sample. The observed mean values of Fe for roadside, market area, residential area in the study were lower than those reported for Fe by Alobaidy \& Mashhadi (2013) for roadside (1902.58 mg/kg, market area $(1989.78 \mathrm{mg} / \mathrm{kg})$ and residential area $(2284.12 \mathrm{mg} / \mathrm{kg})$ respectively in their studies on heavy metal contaminations in urban soil within Baghdad city, Iraq. The anthropogenic sources of Fe have been reported to include the iron and steel activities, sewage and dust from Fe activities (Garba and Abubakar, 2018).

\section{2: Contamination Index}

Contamination index of the heavy metals from the results analyzed is discussed under Enrichment Factor (EF), Pollution Load Index (PLI), Combined Pollution Index (CPI) and Metal Pollution Index (MPI).

\section{3: Enrichment Factor (EF)}

The enrichment factor results are presented in Table 5. The minimal enrichment and high enrichment values of EF (10.04-20.86) as shown in Table 5, indicate that significant heavy metals pollution is likely to come from the anthropogenic activities. 
Table 5: Enrichment Factor for Heavy Metals

\begin{tabular}{llllllll}
\hline Sampling Locations & $\mathbf{P b}$ & $\mathbf{C r}$ & $\mathbf{C d}$ & $\mathbf{M n}$ & $\mathbf{N i}$ & $\mathbf{Z n}$ & $\mathbf{C u}$ \\
\hline Motor park & 3.75 & 0.13 & 20.86 & 0.17 & 0.11 & 0.12 & 0.10 \\
Major Roadside & 2.96 & 0.10 & 14.26 & 0.15 & 01.0 & 0.10 & 0.08 \\
Market Area & 3.76 & 0.15 & 18.72 & 0.14 & 0.13 & 0.12 & 0.09 \\
Residential Area & 2.54 & 0.12 & 6.37 & 0.09 & 0.12 & 0.13 & 0.08 \\
School Area & 1.24 & 0.10 & 0.18 & 0.05 & 0.06 & 0.07 & 0.05 \\
Hospital Area & 1.03 & 0.07 & 0.22 & 0.07 & 0.12 & 0.09 & 0.04 \\
Control Sample & 0.487 & 0.01 & 0.03 & 0.04 & 0.01 & 0.06 & 0.01 \\
\hline
\end{tabular}

In Table 5, the EF values of the heavy metals in the different land use areas were all higher than the EF values of the control location.

The sequential pattern of EF values revealed that the urban soils of the study area were highly enriched with heavy metals such as $\mathrm{Cd}, \mathrm{Pb}, \mathrm{Zn}$ and $\mathrm{Ni}$ which were observed to show extremely high enrichment, while $\mathrm{Cr}, \mathrm{Cu}$ and $\mathrm{Mn}$ were observed to show significant enrichment. These results agree with findings of the study by Alobaidy et al., et al., (2013), in that, they observed that $\mathrm{Pb}$ and $\mathrm{Cd}$ were extremely highly enriched heavy metals in urban soils within Baghdad, the study area. Bello et al., (2016) pointed out that EF values are significantly higher than 1, which indicated that the origin of heavy metals is from anthropogenic sources such as vehicle emission, industrial discharges and other activities. Moreover, some of the heavy metals for the study were highly toxic for humans, so the risks of their potential entry in the food chain must be carefully considered.

\section{4: Metal Pollutions Load Index}

The metal pollution load index includes, Pollution Load Index (PLI), Combined Pollution Index (CPI) and Metal Pollution Index (MPI) which the calculated results are presented in Table 6, which shows that PLI values were higher than 1 in all cases with the exception of residential area and school area land. The higher values of PLI > 1 in cases of motor park, major roadside, market area and hospital area indicate that the studied locations were polluted as a result of anthropogenic activities. This study seems to agree with the research carried out by Mamum et al., (2015) on potential ecological risk of hazardous elements in different land-use urban soils of Bangladesh. They found out in their study that the PLI of some of the land uses including motor park, major roadside etc. were higher than 1 indicating that the land-use areas were polluted by anthropogenic activities. The study carried out by Zhang et al., (2015) on heavy metal pollution in Eastern China 
revealed otherwise, in that the finding of the study showed that the PLI values of different landuse were lower than 1, indicating non-pollution of the study area. In Table 6, it is observed that almost the studied locations were polluted by anthropogenic activities due to the PLI values higher than 1 .

Furthermore, Table 6 reveals that CPI values were greater than 1 (CPI > 1) in all cases of motor park, major roadside and market area, with the exception of residential area, school area and hospital area. The extent of pollution or contamination indicated by the CPI values in the decreasing order of motor park (1.73) > major roadside (.125) > market area (1.23) > residential area $(0.70)>$ school area $(0.40)>$ hospital area $(0.39)$. The CPI values for motor park, major roadside and market area indicate high pollution while those of residential area, school area and hospital area indicate low pollution. With the CPI values, whether high pollution or low pollution, reveals that the different land uses in urban environment are polluted by heavy metals due to anthropogenic sources. The finding of this study is in agreement with the work on heavy metal contaminations in urban soil in Baghdad done by (Alobaidy \& Mashhadi, 2013). Their study revealed the values in the sequence of pollution as roadside soils (1.36) > commercial area (1.31) $>$ residential area (.098). They observed that the urban soils in Baghdad city were moderately or highly polluted with heavy metals due to anthropogenic sources, as it is the observation or finding made in the present study of Bori urban soil.

The results of Metal Pollution Index (MPI) of the study area are presented in Table 6. The MPI value of the Bori urban soil was 3.57, which is greater than 1, indicating that the urban soil of the studied areas are polluted by heavy metals due to anthropogenic activities. 
Table 6: Metal Pollution Load Index (MPI)

\begin{tabular}{llll}
\hline Sampling Locations & PLI & CPI & MPI \\
\hline Motor Park & 1.45 Pollution & 1.73 High pollution \\
Major Roadside & 1.31 Pollution & 1.25 High pollution & 3.57 pollution \\
Market Area & 1.25 Pollution & 0.70 Low pollution & \\
Residential Area & 0.99 No pollution & 0.40 Low pollution & \\
School Area & 0.99 No pollution & 0.39 Low pollution \\
Hospital Area & 1.02 Pollution & 0.13 Low pollution \\
Control Sample & 0.13 No pollution & \\
\hline
\end{tabular}




\section{5: Correlational Analysis (CA)}

The correlation among heavy metals can be used to speculate their sources. For investigation of intermetal relationship in soils, the concentrations of the heavy metals $(\mathrm{mg} / \mathrm{kg})$ were subjected to correlation analysis and the correlation coefficients are shown in Table 7.

Table 7: Pearson Correlation Coefficient of Heavy Metal contents in Soils.

\begin{tabular}{|c|c|c|c|c|c|c|c|}
\hline \multicolumn{8}{|c|}{ Correlations } \\
\hline & $\mathbf{P b}$ & $\mathrm{Cr}$ & Cd & Mn & $\mathbf{N i}$ & Zn & $\mathbf{C u}$ \\
\hline $\mathrm{Pb}$ & $1^{* *}$ & & & & & & \\
\hline $\mathrm{Cr}$ & $.975^{* *}$ & $1^{* *}$ & & & & & \\
\hline $\mathrm{Cd}$ & $.989^{* *}$ & $.944^{* *}$ & $1^{* *}$ & & & & \\
\hline $\mathrm{Mn}$ & $.974^{* *}$ & $.920^{* *}$ & $.980^{* *}$ & $1^{* *}$ & & & \\
\hline $\mathrm{Ni}$ & $.948^{* *}$ & $.960^{* *}$ & $.911^{* *}$ & $.912^{* *}$ & $1^{* *}$ & & \\
\hline $\mathrm{Zn}$ & $.991^{* *}$ & $.981^{* *}$ & $.967^{* *}$ & $.951^{* *}$ & $.971^{* * *}$ & $1^{* *}$ & \\
\hline $\mathrm{Cu}$ & $.994^{* *}$ & $.998^{* *}$ & $.972^{* *}$ & $.964^{* *}$ & $.963^{* *}$ & $.995^{* *}$ & $1^{* *}$ \\
\hline
\end{tabular}

Results show that positive correlation exists among the heavy metals under study as indicated in Table 7. The highly positive correlation among heavy metals in the studied sample soils suggests that the heavy metals in soils have similar pollution sources. The results of the study were in consonant with the findings of study carried out by Meng et al., (2017) on soils in China. Their findings revealed positive correlation among $\mathrm{Cd}, \mathrm{Cu}, \mathrm{Pb}, \mathrm{Zn}, \mathrm{Cr}$ and $\mathrm{Ni}$ which indicated the similar pollution sources and combined soil pollution by multi-heavy metals.

Therefore, the positive correlation among heavy metals in sample soils of the study indicate the combined soil pollution by multi-heavy metals due to rapid urbanization and development as well as human activities.

\section{0: CONCLUSION}

Heavy metal contaminations in surface soils within Bori urban were examined. Seven heavy metals $(\mathrm{Pb}, \mathrm{Cr}, \mathrm{Cd}, \mathrm{Mn}, \mathrm{Ni}, \mathrm{Zn}, \mathrm{Cu}$ and $\mathrm{Fe})$ in the different sampling locations were investigated including the control location. From the results, the combined pollution index of $3.57>1$ revealed that the urban soil of the study area is polluted. Based on the findings, the urban surface soils of the study area are polluted with heavy metals. Therefore, there should be monitoring and environmental audit by the relevant authorities to ensure adequate environmental quality of the soil in Bori urban. 


\section{0: REFERENCES}

Al Obaidy, A. J. \&Mashhadi, A. M. (2013). Heavy metal contaminations in Urban soil within Baghdad City, Iraq. Journal of Environmental Protection, 4(1): 72-82.

Ali, Z. Malik, R.N., Shinwari, Z.K., \& Qadir, A. (2013). Environment, risk assessment, and statistical apportionment of heavy metals in tannery-affected areas. International Journal Environment, Science and Technology, 12:537-550.

Bello, S. Zakari, Y. I., Ibeamu, I. G. E. \& Muhammad, B. G. (2016). Characterization and assessment of heavy metal pollution levels in soils of Dana steel limited dumpsite, Katsina State, Nigeria using geoaccumulation, ecological risk and hazard indices. American Journal of Engineering Research, 5(1): 4961.

Edori, O. S. \& Kpee, F. (2017). Index models assessment of heavy metal pollution in soils within selected abattoirs in Port Harcourt, Rivers State, Nigeria. Singapore Journal of Scientific Research, 7(1):9-15.

Ekwere, A. S., Ekwere, S. J., Ephraim, B. E., \&Ugbaja A. N. (2014). Distribution of heavy metals in urban soils: A case study of Calabar Area, South-Eastern Nigeria. Geosciences, 4(1): 23-28.

Garba, S. T. \&Abubakar, M. A. (2018). Source and distribution of the heavy metals: $\mathrm{Pb}, \mathrm{Cd}, \mathrm{Cu}, \mathrm{Zn}, \mathrm{Fe}$, $\mathrm{Cr}$, and $\mathrm{Mn}$ in soils of Bauchi Metropolis, Nigeria. American Journal of Engineering Research, 7(2), 1323.

Hamid, A., Riaz, H., Akhtar, S. \& Ahmad, R. S. (2016). Heavy metal contamination in vegetables, soil and water and potential health risk assessment.American- Eurasian journal of Agricultural and Environmental Sciences, 16(4): 786-794.

Iwegbue, C.M., Bassey, F. I., Tesi, G. O. Nwajei, G. E. \&Tsafe, A. I. (2013). Assessment of heavy metal contamination in soils around cassava processing mills in sub-urban areas of Delta State, Southern Nigeria.Nigerian Journal of Basic and Applied Science, 21(2): 96-104.

Jin, Y. L. Zhang, Y. E., Min, J., Sun, J. F. \& Liu, P. (2014). The application of individual margin of exposure in the health risk assessment of dietary exposure to lead.Chinese Journal of Health Statistics, 31(6): 943-945.

Karim, Z., Qureshi, B. A. \&Mumtaz, M. (2015). Geochemical baseline determination and pollution assessment of heavy metals in urban soil of Karachi, Pakistan.Ecological Indicators, 48:358-364.

Li, B. \& Tan, C. (2016). Distribution and risk evaluation of heavy metal in the soil of typical grassed swale. MATEC Web of Conferences 59, 04001.

Liang, J. Chem, C., Song, X; Han, V. \&Liand, Z. (2011). Assessment of heavy metal pollution in soil and plant from Dunhua sewage irrigation area.International Journal of Electrochemical Science, 6: $5314-$ 5324.

Lu, S.G. \&Bai, S.Q. (2010). Contamination and potential mobility assessment of heavy metals in urban soils of Hangzhou, China: Relationship with different land uses. Environmental Earth Sciences, 60(7): 1481-1490.

Marcus, A. C., Nwineewii, J. D. \& Edori, O. S. (2017). Heavy metals assessment of leachate contaminated soils from selected dumpsites in Port Harcourt, Rivers State, South-South Nigeria. International Journal of Chemical Studies, 5(6):1507-1511.

Meng, W., Liu, L., Zhou, J., Hu, B. \& Wang, Z. (2017). Assessment of heavy metal pollution and potential ecological risk in soils of Tianjin sewage irrigation Region, North China.Journal of Environmental and Analytical Toxicology, 7(1), 1-6. 
Michael, A. T. Daniel, U. D., Jibrin, U. \&Benard, A. B. (2015). Distribution and variation of heavy metals and soil properties around a mega cement factory in Gboko, Benue State, Nigeria. International Journal of Science and Technology, 4(8), 385-394.

Mmolawa, K. B., Likuku, A. S. \&Gaboutloeloe, G. K. (2011). Assessment of heavy metal pollution in soils along major roadside areas in Botshwang.African Journal of Environmental Science and Technology 5(3), 186-196.

Mohamed, R., Erhanyem, M., Ahmida, K., Fatama, A. \&Abdusallam, Z. (2015). Assessment of heavy metal contamination in soils of Sirte city, Libya. $2^{\text {nd }}$ International conference on Advances in Environment, Agriculture and Medical Sciences, Antalya (Turkey) June 11-12.

Nezhad, M. T. K., Tabatabaii, S. M., \&Gholami, A. (2015). Geochemical assessment of steel smelter impacted urban soils. AHAVZ, Iran. Journal of Geochemical Exploration, 152: 91-109.

Nwineewii, J. D. \& Nna, P. J. (2016). Impact of Eleme Petrochemical Company (Indorama) on the levels of some heavy metals in penausmonoden (Shrimp) from Eleme creeks, Rivers State, Nigeria. Academic Research International, 7(4): 47-57.

Ogundele, D. J., Adio, A. A. \&Oludele, O. E. (2015). Heavy metal concentrations in plants and soil along heavy traffic roads in North Central Nigeria.Journal of Environmental and Analytical Toxicology 5(6); 1-5.

Ogunkunle, C. O., Fatoba, P.O., Ogunkunle, M. O. \&Oyedeji, A. A. (2013). Potential health risk assessment for soil heavy metal contamination of Sagamu, South-west Nigeria due to cement production.International Journal of Applied Science and Technology, $\quad 3(2): 89-96$.

Oladeji, J. T., Adetola, S. O., \&Ogunsola, A. D. (2016). Heavy metal concentrations in soil of Ogbomoso and its environs.Merit Research Journal of Environmental Science and Toxicology, 4(1): 001-005.

Onweudike, S. U., Igbozurike, C. I., Ihem, E. E., Osisi, F. A. \&Ukah, C. I. (2017). Quantification of heavy metals using contamination and pollution index in selected refuse dumpsites in Owerri, Imo State, Southeast Nigeria.International Journal of Environment, Agriculture and Biotechnology, 2(2): 1201-1208.

Proshad, R., Islam, M. S., Kormoker, T. Bhuyan, M. S. Hanit, M. A., Hossain, N., Roy, R. \& Sharma, A. C. (2019). Contamination of heavy metals in agricultural soils: Ecological and health risk assessment. Science Forcast Journal of Nanochemistry and Nanotechnology, 2(1), 1-13.

Salah, E. A., Yassin, K. H and Sata, A, (2015). Level distribution and pollution assessment of heavy metals in urban community garden soils in Baghdad City, Iraq.International Journal of Scientific and Engineering Research 6(10) $1646-1652$.

Sarala, T. D., \&Uma, M. T. (2013). Metal pollution assessment in ground water. Bulletin of Environment, Pharmacology and Life Sciences, 2(12),:122-129.

Wang, G., Liu, H., Gong, Y, Wei, Y., Miao, A., Yang, L. \&Zhong, H. (2017).Risk assessment of metals in urban soils from a typical industrial city, Suzhou, Eastern China.International Journal of Environmental Research and public health, 14(1025): $1-17$.

Zhang, L. Liao, Q., Shao, S. Zhang, Q. \& Liu, C. (2015).Heavy metal pollution, fraction and potential ecological risks in sediments from lakeChaohu (Eastern China) and the surrounding rivers.International Journal of Environmental Research and Public Health, 31(2):112-115. 